\title{
Anesthesia Today With the Economic and Clinical Aspects
}

\author{
Branislava M. Majstorović ${ }^{1}$, Branko D. Milaković ${ }^{1,2}$, Srdjan Z. Marković ${ }^{3}$, \\ Dragana A. Kastratović ${ }^{3}$ \\ ${ }^{1}$ Center of Anesthesiology and Reanimation, Clinical Center of Serbia, Belgrade, Serbia \\ ${ }^{2}$ Medical Faculty, University of Belgrade, Belgrade, Serbia \\ ${ }^{3}$ Center of Clinical Pharmacology, Clinical Center of Serbia, Belgrade, Serbia
}

\section{SUMMARY}

Introduction: The rapid development of knowledge and technology conditions the use of pharmacoeconomic and economic analysis in the system of market economy in health care. Pharmacoeconomics identifies, measures, compares and analyzes the relationship between costs and outcomes of the use of pharmaceutical products.

Corresponding section headings: This review article, presents the results of our research in the field of hospital pharmacoeconomics in anesthesia in the Clinical Center of Serbia through published pharmacoeconomic studies from 2007 to today. In our years-long research we have given a description of the analysis of direct and indirect costs, assess the quality of treatment, efficiency and effectiveness to cost-benefit analysis of different techniques and types of anesthesia in the context of different surgical disciplines. Dispete The economic evaluation of medicines are increasingly important to medical authorities. Clinical pharmacology should be included as a way to rationally promote efficiency and effectiveness of the disease treatment.

Conclusion: Economic and pharmacoeconomic assessments put emphasis on the quality of treatment and the potential gains for the public and individual patients. Probably the highest quality of medical services (the most effective drugs, enough staff, and new safer medical equipment) showed as less expensive and have made the economic analysis more rational in the context of the total budget. More investment is creeper health.

Keywords: anesthesia, pharmacoeconomia, health

\section{INTRODUCTION}

The rapid development of knowledge and technology conditions the use of pharmacoeconomic and economic analysis in the system of market economy in health care. Pharmacoeconomics identifies, measures, compares and analyzes the relationship between costs and outcomes of the use of pharmaceutical products. Unlike pharmacoeconomic assessment, medical economic assessment analyze health outcomes as part of the cost of the entire treatment and refer to the comparison of non-pharmacological therapy (Surgical interventions, prevention strategies to preserve health, the usefulness of medical equipment, hotel accommodation, etc.)

Anesthesia is specialized in multi- 
plicity and frequency of administration, as an element of clinical support in all areas of medicine. Anesthesia is a special surgical discipline participating in the diagnosis and treatment of many, especially surgical diseases, and healthy individuals (etc. cosmetic surgery). Every year, 230 million patients worldwide receive anesthesia for surgery. Of this number, 7 million patients develop complications of surgical intervention, 1 million fatal (200. 000 in Europe) [1]. Anesthesiology deals with preoperative preparation for anesthesia, using different types and techniques of general and local anesthesia during surgery and postoperative recovery of patients with possible complications in resolving the Unit for intensive care and beyond. We wish to emphasize that in clinical practice ethical principles are always over economic calculation [2].

The goal of these studies is to evaluate the feasibility of intraoperative application of general and local anesthesia for the same type of surgery, measure the height of the cost of post-operative treatment in the Intensive Care Units for (ICU), Units for treatment of pain and assess validity of budget allocation within the health system, etc. Cost estimate is obtained by multiplying the measured spent funds with fees ("unit costs"). Unit costs can be obtained from the financial services or from the official price list.

In our years-long research we have given a description of the analysis of direct and indirect costs, assess the quality of treatment, efficiency and effectiveness to cost-benefit analysis of different techniques and types of anesthesia in the context of different surgical disciplines.

Medical economic analysis and assessment individually, for one kind or type of surgical intervention is the subject of our further studies that are underway. Health economy as the most important part of the general economy, and pharmacoeconomics as part of hospital clinical pharmacology are the recently applied sciences slowly developing its methodology in the interest of safety, savings, evaluation, development and availability of new medical technologies (drugs, therapeutic procedures, medical devices).

\section{CORRESPONDING SECTION HEADINGS}

This review article, presents the results of our research in the field of hospital pharmacoeconomics in anesthesia in the Clinical Center of Serbia through published pharmacoeconomic studies from 2007 to today.

The method of activity based costing, activity-based costing (ABC) administrates hospital costs by activities. Consumption of resources in the Clinical Center was divided into: internal medicine and surgical expenses, in the context of infectious diseases, etc.; clinical support unit costs (anesthesiology, clinical biochemistry, radiology, hospital clinical pharmacology, etc.); and the cost of outpatient activities (emergency services, clinics, day surgery, rehabilitation, dialysis, etc.). Costs of anesthesiology are interpreted as costs of clinical support surgery as a clinical center consumption [3]. Costs relate to the consumed resources in providing anesthesia services.

In addition to the list of procedures for the calculation of costs, we needed the cost of input and output parameters. The input parameters were the funds spent in salaries of doctors and anesthetist (personnel costs); anesthetics and other drugs used in anesthesia; medical and non-medical supplies and laboratory analyzes necessary for anesthesia; prices for amortized appliances and machines used for the application of anesthesia and monitoring vital functions; "Hotel" accommodation of patients (30\% of the cost of hospital days). Output parameters were: length of anesthesia and duration of treatment in the ICU.

Direct medical costs were the sum of: personnel costs, drugs, materials, and other costs. Other costs included the required biochemical and hematological analysis, electrocardiogram (ECG) and X-ray of the lungs, necessary for anesthesia, as well as the value of medical equipment used in anesthesia and "hotel" for accommodation of patients (30\% of the cost of hospital days) etc.

Indirect costs result from the reduction of working capacity due to illness, disability or death. Indirect costs are calculated on the basis of the average gross personal income of employees. Average costs for anesthesia were counted by dividing the number of direct costs of anesthesia and anesthetic procedures. The average cost per patient were counted by dividing the number of direct costs of patients that received anesthesia. We counted correlation personnel costs, drugs and materials, and other costs by elements with a total direct costs in anesthesia in the context of different surgical 
disciplines. After, we compared the direct costs to the average length of general anesthesia per minutes in surgical disciplines. Center for anesthesia (CA), the Economic and Financial Services (EFS), Centre for Clinical Pharmacology (CCP), the Centre for Social Medicine and Medical Statistics (CSMS), Center for medical supply as well as Republic Health Insurance Fund, Serbia (RHIF) were used for all studies from database of the Clinical Center of Serbia (KCS).

The results of the direct costs of anesthesia showed that personal income tax accounts for $40 \%$; medicines and materials with $31.80 \%$ and other costs with $28,20 \%$ of resources [4]. Perioperative costs, only for a given anesthesia during surgery would enlarge the costs of surgical procedures by $10 \%$ [5].

In order to understand the functioning of real RHIF support of hospital health care in the field of anesthesia, it was necessary, and interesting to determine the relationship between the elements of direct costs derived from clinical trials, with a package of anesthesia services refunded by RHIF $[6,7,8]$. We compared the linear model data of the direct costs of "unit costs" obtained from the HIF price list. HIF price list is regulated by the Council of the Republic Fund of health care and health insurance in 1990 and adjusted occasionally on annual bases. Correlation of direct costs shows a linear correlation with the exception of neurosurgical anesthesia, including the HIF" unit prices". The reason is, according to our opinion, organizational division of neurosurgical services in the two clinics, Neurosurgical and Emergency Center. Organization of the Department of Anesthesiology and ICU and way of financing health care affect costs $[4,5,6]$

As a measure of the effectiveness or cost effectiveness are used the scores of improved life quality related to health. Because its key constraint is one-dimensional, we analyzed patient treatment satisfaction (effectiveness of the final outcome). Medical services were satisfied with $73 \%$ of anesthetized surgical patients [6], according to the survey which formed part of the program for monitoring and improving the quality of work in health institutions HIF [6]

The sequence of the analysis. Personnel costs are fixed, direct costs, which do not depend on the number of patients, and are charged on the basis of the Regulation on the coefficients in public services [9]. It would not be proper to compare with other countries because of different methodology for calculating personal income. For decades in the transition, it would not be appropriate to comment further reduction in personal income as a possibility to reduce the cost of treatment, because the salary of doctors in Serbia is among the lowest in the world.

Medicines, medical and non-medical supplies are real and transparent costs of treatment, and as such are subject to continuous check and requirements to reduce costs by hospital and government administration. Internationally accepted methodology for defined daily doses (DDD Defined Daily Doses) and Anatomical Therapeutic Chemical (ATC) classification of drugs registered in Serbia was used to study the consumption of anesthetics and other medications. The DDD is the assumed average maintenance dose per day for a drug used for its main indication in adults, and it is expressed in mass unit. General and local anesthetics, muscle relaxants, and i. v. solutions as well as other drugs, do not have established DDD, therefore it is recommended an alternative way of displaying data in a unit doses (UD-unit doses), or a single dose [10]. Some of the characteristics of anesthetics and other drugs used in anesthesia are: a one-time application, simultaneous use of multiple drug classes are strong facts, different single dose of the same drug (induction and maintenance of anesthesia), only intravenous or inhalation drug use, continuous intravenous anesthetics, muscle relaxants and other drugs via pumps or Infusomats etc. The same drugs can be used preoperatively, operatively, and postoperatively. Storage capacity of dissolved drugs is limited. Groups of drugs was calculated as: general and local anesthetics, analgesics, benzodiazepines and opiate antidotes, muscle relaxants, adrenergic agents, blood substituents, solutions for intravenous administration (parenteral nutrition, electrolyte imbalance, electrolyte solutions), etc. Possible differences in costs incurred between surgical disciplines would give the ability to identify elements that could be affected, in terms of rationalization of costs in anesthesiology departments. Our studies have shown that the funds for anesthetics and other drugs used in anesthesia cover $5.93 \%$ of the funds for medicines KCS [10, $11,12]$. Internal and surgical services as larger centers have higher clinical consumption of drugs [3]. Cost of inhalation anesthetics were 
$22.3 \%, 16.6 \%$ of intravenous and muscle relaxants $14.9 \%$. Considering the total local anesthetics consumption, local anesthetics include $1.2 \%$ of the funds for anesthetics and other drugs used in anesthesia.

We do not intend to influence the choice of economy of drugs, so as not to affect the quality of anesthesia, stating, however, that drug companies through the recent prices, now standard, drugs for anesthesia, influence the quality of anesthesia. From the group of inhalation anesthetics, Halothane, which has been in use for more than half a century gave way to newer, Sevorane, with a price 240 times higher than the price of Halothane. In the group of intravenous anesthetic etomidate was present 10 times less than propofol and was three times cheaper than propofol. From the group of local anesthetics lidocaine was used 10 times more than mepivacaine, which is 200 times more expensive than lidocaine, etc $[10,11,12]$. Is the price in line with the costs of production, or the greater because of the quality of anesthesia for which doctors fight?

Our results, which show a significant association between high personnel costs, consumption of anesthetics and drugs with direct costs, do not indicate the possibility of further cost reductions $[11,12]$. The reason is the lack of direct costs and "unit price" including the type and technique of anesthesia specific duration, per hour, according to a price list [13], agreed with the Health Insurance Fund. As for direct costs, only costs of anesthetics, drugs and materials are realistic, and all the other elements are determined by law and by contract with HIF. Due to restrictive health budget, funds available to HIF are reduced to maximum. Even though it is not the subject of this paper, in the the literature is stated that small savings of funds in direct costs in anesthesia is possible by reducing the cost of procurement of drugs, reducing the 'waste' of i.v. anesthetics (ampoules shell not be open in advance) but not the choice of anesthetic so as not to affect the quality of anesthesia. Potential savings factors may include: low flow rates of gases in anesthesia, the use of local anesthetic where possible, the use of Infusomats and pumps precisely dosing and reducing the consumption of drugs [14]. Other expenses, from the group of direct costs would be theoretically reduced by performing analysis necessary for anesthesia, for a planned surgical intervention in primary health care.
We did not get even a linear or regression correlation of the average cost of anesthesia services to the length of anesthesia in surgical specialties $[10,15,16]$. It is not very important but it is useful in terms of determining the real price of treatment. Organization of anesthesia department, ICU and the method of financing health care affect costs as well. Costs are not always correlated with the current prices. The objective is financing costs, which are based on the actual consumption of resources (medical personnel, knowledge, time, facilities, equipment), for each service provided $[17,18]$.

According to our research the profitability of endovascular treatment compared with conventional neurosurgical intervention clipping, is associated with lower morbidity, mortality, and higher prices for all ruptured and unraptured aneurysms during hospitalization. Direct medical costs were calculated from the perspective of the National Health Insurance Fund (NHIF). Endovascular treatment was associated with a $3 \%$ of side effects, lower mortality ( $2 \%$ vs. $2.9 \%$ ), significantly shorter length of stay $(Z=-8.566, p<0.01)$ and higher costs $(Z=-12.475, p<0.01)$ in relation to the neurosurgical treatment. A statistically significant difference was mainly determined by the price of embolismic materials, average 328.169 RSD ( $€$ 3.111) and the number of solved aneurysms (more than one, when solved multiple aneurysms) $[19,20,21]$

Improving the quality of life related to health is one of the main economic assessment of rationality of medical services. The results of user satisfaction surveys to health care services carried out in the Surgical Clinic by HIF are stated herein. Overall treatment included: $0.4 \%$ of the very dissatisfied patients, $2.2 \%$ dissatisfied, $16.1 \%$ neither satisfied nor dissatisfied, $73 \%$ satisfied and there was no very satisfied patients.

Economic and pharmacoeconomic assessments put emphasis on the quality of treatment and the potential gains for the public and individual patients. Resources are allocated at the level of Government. States determine financial resources for the community on the basis of gross domestic product per capita (GDP) and according to the health status of the population or the Index of Health. General and specific rates of morbidity (sickness), rates of absenteeism and the degree of invalidity indicate health population [21, 22, 23]. Despite 
these problems, the economic evaluation of medicines are increasingly important to medical authorities. Clinical pharmacology should be included as a way to rationally promote efficiency and effectiveness of the disease treatment.

\section{CONCLUSION}

Health care costs are rising especially in the challenging vital areas of medicine such as anesthesia. Studies have shown that salaries "spend" most of the funds (40\%), drugs and supplies (32\%) and other expenses are lower (28\%). Within surgical costs, perioperative anesthesia accounts for 10\% (ABC analysis). Anesthetics and other drugs used in anesthesia spend less than $5 \%$ of the funds for hospital medicine. Significant attention has been given to price of anesthetics and drugs, particularly to the cost of newer, faster-acting inhalation anesthetics, intravenous analgesics and neuromuscular blockers. We believe that small savings of funds by reducing procurement costs is possible but not the selection of anesthetic so as not to affect the quality of anesthesia.

In terms of small and restrictive national health budget there is no room for cuts in salaries, anesthetics and medicines as well as other direct costs of anesthesia. Pharmacoeconomic and economic evaluation of new drugs, medical devices and technologies, are needed at the local and global level in order to make possible savings, assess existing and introduce new, more efficient and effective methods of treating diseases.

We shall point that basic information on hospital activity should be more specific, accurate and transparent. Clinical protocols of anesthetized patients can be better linked to the outpatient, departments, intensive care units and daily surgical hospitals. Databases of Clinical drug procedure and Bookkeeping of Information System and hospital information system management should be better managed, more precise and specific.

Probably the highest quality of medical services (the most effective drugs, enough staff, and new safer medical equipment) showed as less expensive and have made the economic analysis more rational in the context of the total budget. More investment is creeper health.

\section{REFERENCES}

1. Weiser TG, Regenbogen SE, Thompson KD, et al. An estimation of the global volume of surgery: a modelling strategy based on available data. Lancet 2008; 372: 139-14.

2. Novaković T. Priručnik za farmakoekonomske evaluacije. Crown Agents-Project. Beograd 2006.

3. TA for Capacity Building for Tertiary Care Services Republic of Serbia. A project funded by the European Union. Belgrade: Ministry of Health of the Republic of Serbia, European Investment Bank / Sofreco; 2006.

4. Majstorović BM, Kastratović DA, Vućović DS, Milaković BD, Miličić BR. Operating cost analysis of anaesthesia: activity based costing ( $A B C$ analysis). Srp Arh Celok Lek. 2011; 139(7-8):501-8.

5. Majstorović BM, Milaković B.Isplativost i korisnost zdravstvenih intervencija u sistemu zdravstvene zaštite-Ekonomska analiza anesteziološkog rada-. Zdravstvena zaštita.2010; 29(5):23-33. On Serbian.

6. Majstorovic BM, Milaković BD, Marković SZ, Mijajlović MS, Kastratović DA. The Results and Methodological Concerns about Pharmaco-Economic Evaluation in Anesthesia. Hospital Pharmacology - International Multidisciplinary Journal; 2014;1(2):68-75. (www.hophonline.org)

7. Majstorović BM, Vučović DS, Milaković BD, Mikov MM, Mijajlovic MS, MarkovicSZ, Kastratović DA. The Analysis of Direct Costs in Anesthesia. Journal of Pharmacy Research. 2011; 4(10):3520-24. (www; pronline.info)

8. Majstorović BM, Simić S, Milaković BD, Vucović DS, Aleksić VV. Descriptive analysis of work and trends in anaesthesiology from 2005 to 2006: quantitative and qualitative aspects of effects and evaluation of anaesthesia. Srp Arh Celok Lek. 2010 SepOct;138(9-10):624-31. Serbian. PMID: 21180093.

9. By-laws on coefficients for the calculation and payment of workers' salaries in the public services. Official Gazette of the Republic of Serbia 106/2006.

10. Kastratović AD, Dukić BV, Majstorović MB, Komarski JJ, Gajić MM, Marković SZ. Antibiotic consumption monitoring at the Institute of Otorhinolaryngology and Maxillofacial Surgery-Clinical Center of Serbia in 2001-2003. Vojnosanit Pregl. 2005; 62(7-8): 551-5.

11. Majstorović BM, Kastratović DA, Milaković BD, Marković SZ, Mijajlović MS, Vucović DS. Cost of anestetics and other drugs in anesthesia. Med Pregl. 2012; 65(1-2):30-4. Serbian.

12. Majstorović BM, Milaković BD, Kastratović DA, Milićić BR, Vucićević VR. Reductions in anesthesia direct costs is not the right way for racionalization of anesthesia costs. Med Pregl. 2012 Sep-Oct;65(910):421-7. Serbian. 
13. Odluka o zajedničkim kriterijumu i merilima za utvrđivanje cena zdravstvenih usluga. Službeni glasnik Republike Srbije 3/91. Serbian.

14. Stevanovic PD, Petrova G, Miljkovic B, Scepanovic R, Perunovic R, Stojanovic D. Low fresh gas flow balanced anesthesia versus target controlled intravenous infusion anesthesia in laparoscopic cholecystectomy: a cost-minimization analysis. Clin Ther. 2008; 30(9):1714-25.

15. Majstorović MB, Vučović $D$, Milaković $B$, Kastratović D, Gajić M. Anesteziološki rad, direktni $\mathrm{i}$ indirektni $\mathrm{i}$ ukupni troškovi anestezije $\mathrm{i}$ anestezioloških usluga 2006. godine u Institutu za neurohirurgiju Kliničkog centra Srbije. Anestezija i intenzivna terapija. 2007;30(2):71-79. Serbian

16. Majstorović BM, Kastratović DA, Vućović DS, Milaković BD, Gojković-Bukarica LjČ, Pekmezović TD. Farmakoekonomska procena troškova u anesteziologiji / Pharmaco-Economic Estimation of Cost in Anesthesiology. Pharmaca Serbica 2009;1(1.2):3640.

17. Schuster MA, Standl T.Cost drivers in anesthesia: manpower, technique and other factors. Current Opinion in Anesthesiology.2006;19(2):177-184.

18. Meyer-Jark T, Reissmann H, Schuster M, Raetzell $M$, Rosler L, Petersen F, et al. Realisation of material costs in anaesthesia. Alternatives to the reimbursement via diagnosis-related groups.

Anaesthesist. 2007; 56(4):353-62, 364-5.

19. Majstorović BM, Milošević-Medenica SB, Milaković BD, Naumović TS. New Interventional Neuroradiological Procedures in Serbia- The Direct Costs of Classical Neurosurgical Intervention in Relation to the Endovascular Treatment of Intracranial Aneurisms. Hospital Pharmacology - International Multidisciplinary Journal. 2015: 2(2); 272-278. (www.hophonline.org)

20. Majstorović BM, Prstojević B, Milaković B. Anesteziološki aspekt dijagnostičkih i interventnih neuroradioloških procedura u Kliničkom centru Srbije. Anestezija i intenzivna terapija. 2009;32(1): 19-32.

21. Majstorović BM, Milaković BD. Anesthetic Services in Serbia. Hospital Pharmacology - International Multidisciplinary Journal. 2016; 3(1):361-369. (www.hophonline.org)

22. Vuković MH, Jakovljević MB. Structural validity and reliability of the healthcare professionals' economic reasoning questionnaire. Hospital Pharmacology - International Multidisciplinary Journal. 2015; 2(3):308-316. (www.hophonline.org)

23. Jakovljević MB. Health Expenditure Dynamics in Serbia 1995-2012. Hospital Pharmacology - International Multidisciplinary Journal. 2014; 1(3):180183. (www.hophonline.org) 


\section{Anestezija danas sa ekonomskog i klinickog aspekta}

Branislava M. Majstorović ${ }^{1}$, Branko D. Milaković ${ }^{1,2}$, Srdjan Z. Marković ${ }^{3}$, Dragana A. Kastratović ${ }^{3}$

${ }^{1}$ Institut za anesteziju i reanimaciju Kliničkog centra Srbije u Beogradu, Beograd, Srbija

${ }^{2}$ Medicinski fakultet Univerziteta u Beogradu, Beograd, Srbija

${ }^{3}$ Centar za kliničku farmakologiju Kliničkog centra Srbije u Beogradu, Beograd, Srbija

\section{KRATAK SADRŽAJ}

Uvod: Ubrzani razvoj znanja i tehnologije, uslovljava primenu farmakoekonomskih i ekonomskih analiza u sistemu tržišne ekonomije u zdravstvu. Farmakoekonomija identifikuje, meri, upoređuje i analizira odnos troškova i ishoda korišćenja farmaceutskih proizvoda.

Tema revijanog rada: Ovim revijalnim radom, kroz publikovane farmakoekonomske studije od 2007 do danas, prikazujemo rezultate naših istraživanja iz oblasti bolničke farmakoekonomije u anesteziji u Kliničkom Centru Srbije. U našim višegodišnjim istraživanjima dali smo opis, analizu direktnih i indirektnih troškova, procenu kvaliteta lečenja, efikasnost i efektivnost do analize isplativosti različitih tehnika i vrsta anestezije u okviru različitih hirurških disciplina. Uprkos brojnim problemima vezanim za budžet i organizaciju, ekonomske procene lekova su sve važniji u odluci onima koji donose odluke. Bolnička Klinička farmakologija bi trebalo da sa priključi kao način za racionalno promovisanje efikasnosti i efektivnosti lečenja bolesti.

Zaključak: Ekonomske i farmakoekonomske procene stavjaju naglasak na kvalitet tretmana i potencijalne dobiti javnog i individualnog zdravlja. Verovatno bi se najkvalitetnija medicinska usluga (najefikasniji lekovi, dovoljno kadra, nova bezbednija medicinska oprema) pokazale jeftinijim i učinile ove ekonomske analize racionalnijim u okviru ukupnog budžeta. Veće investicije daju jeftinije zdravlje.

Ključne reči: anestezija, farmakoekonomija, zdravlje 